\title{
Reviews of The Nay Science
}

CrossMark

\section{Edward P. Butler, John R. Lenz, Antonio Luis Costa Vargas, Doug McGetchin * (D, Bruce M. Sullivan, Jeffery D. Long, Robert Yelle, David Cerequas, Na'aman Hirschfeld, Veena R. Howard and Purushottama Bilimoria}

\author{
* Correspondence: \\ dmcgetch@fau.edu \\ Florida Atlantic University, Jupiter, \\ Florida, USA
}

\author{
The Nay Science: A History of German Indology \\ By Vishwa Adluri, Joydeep Bagchee \\ New York: Oxford University Press, 2014.
}

\section{Written in a soul: Notes toward a new (old) philology}

Acknowledgement: This essay was written by Edward P. Butler, Independent Scholar.

The critique of German Indology in The Nay Science is aimed not merely at disclosing the ideologies and discourses of power animating the work of a certain body of researchers in a single subdiscipline of the humanities, but rather, as its Prologue reveals, at freeing space through this critique for the emergence of a new philology.

German Indology proves the ideal point from which to launch this critique for several overlapping reasons. German Indology is linked to an event of world historical importance, namely the project of German nationalist intellectuals to appropriate for themselves an "Aryan" identity. Furthermore, German Indology constituted the cutting-edge of European intellectual response to the challenge of Indian thought, an unbroken polytheistic intellectual tradition reaching back to antiquity, which by its very existence implicitly called into question the sundered relationship of European thinkers to their own antiquity. And Indology provided a model for the application of the positivistic ideals of nineteenthcentury philology to the works of other civilizations which might similarly threaten to participate in the European intellectual conversation not as museum pieces, but as partners in real time, such as Chinese thought, or to complicate the European narrative about its own antiquity, such as the rediscovery of ancient Egyptian and Mesopotamian thought, or about its colonial intentions, as the study of thought from the Americas and Africa.

The critical undertaking launched by The Nay Science therefore must continue to stimulate self-criticism in a host of other philological disciplines, including, especially, Classics, insofar as modern philology is grounded in the peculiar relationship of modern European thought to its roots in pagan antiquity, a relationship of appropriation and would-be sublation implicitly presented as a model to contemporary non-Western civilizations of the relationship to which they might aspire regarding their own traditions, with or without the adjunct proffered them by Christian missionaries. Alongside this critical effort, though, must come the effort toward discerning the principles of a new philology embodying the Platonic sense of a philia or eros toward logos or discourse, in which the search for psychogonic value in texts would be recognized as inseparable from their technical grasp. The Nay Science, with uncommon discipline, deploys the gray archival work of Foucauldian genealogy in the service of this possibility, that future scholars might, looking up from the texts over which

(c) 2016 The Author(s). Open Access This article is distributed under the terms of the Creative Commons Attribution 4.0 International License (http://creativecommons.org/licenses/by/4.0/), which permits unrestricted use, distribution, and reproduction in any medium, provided you give appropriate credit to the original author(s) and the source, provide a link to the Creative Commons license, and indicate if changes were made. 
they are bent, feel once again Boreas's breeze, and it is in service of this project that I wish to contribute some thoughts on philology as it might glimpse itself in Plato's Phaedrus and in another ancient text on writing that has only recently come to light. The recourse to ancient texts in this regard is not a matter of mere recourse to tradition or age as authority. Rather, I wish to argue that it is their comprehensive vision of the situation of the text in relation to mortal being that makes such texts a natural place for us to look for theoretical orientation for a new philology-more so, I believe, than potential alternatives such as Nietzsche or Spinoza, though I do not intend to argue the latter case here.

The Phaedrus is well known for its supposed critique of writing; however, throughout the dialogue Socrates shows a high degree of sensitivity to the nature of texts, and a solicitude toward them that is not in conflict with his account of the text as having no power to defend itself from misappropriation (275e) any more than with his playful probing of the limits of textual correctness, such as when he knowingly quotes a spurious poem of Homer's $(252 \mathrm{~b}-\mathrm{c})$, or says that he is a sufficient mantis for his own purposes, "as the bad writers say" (242c). When Socrates speaks of being a philologos, of being an erastēs of logoi (228c) and so forth, he does not distinguish between spoken and written texts. Thus at $258 \mathrm{~d}$, he sets out to discover "the method of writing well," and then, resuming the task at 259e, adds "and speaking well," without evident contrast. Most importantly, Socrates at the very outset of the dialogue demands of Phaedrus the actual text of Lysias' speech (228d-e). Moreover, the piety that pervades this dialogue ${ }^{1}$ not only extends to the written text, but, I would argue, centers upon it. In this respect I believe that Plato's reference by name, without syncretistic euphemism, to the Egyptian God Thoth (274c) is far from merely decorative. We now possess the text, fragmentary but highly illuminating, of a Demotic initiatory manual for Egyptian scribes, earlier versions of which likely existed already in Plato's day and well before, that offers, as I have argued elsewhere (Butler 2013), a comprehensive metaphysics of writing and of the writer. I would hardly wish to argue that Plato was aware of such a text; rather, the structural parallels I believe can be drawn between the Phaedrus and the socalled (by modern scholars) Book of Thoth come, I would say, from thinkers in two cultures applying themselves to the same problem, namely what is writing, and who is the writer?

Socrates, in the attempt to understand Lysias's text, is compelled, as a philologos, to produce another text himself (236d-e), first articulating Lysias's original point, then his own opposing discourse. We may compare this with what I believe to be one of the cardinal principles articulated in the "Book of Thoth." Thus an aspirant ("the one who loves knowledge") inquires of a figure identifiable as Thoth or his functionary, "What is writing?" eliciting the response that "Writing [or "a book"] is a sea; its reeds are a shore" (B02, 4/12-13 in Jasnow and Zauzich 2005; 351-52 in Jasnow and Zauzich 2014). ${ }^{2}$ Reeds, as the material from which pens are made, represent ongoing textual production; hence, the "shore" of the textual sea is reached by producing further text, and aspiring scribes are urged here and throughout the Book of Thoth to throw themselves into this task and not to await a "fair wind" (B02, 4/14-15 [353-4]; Butler 2013, 217-21) in numerous passages in which the maritime symbolism for enaging with texts constantly evokes parallels from the Egyptian afterlife literature. Socrates, too, of course, finds it necessary in order to give an account of the conditions of truth (247c), to discuss the soul's fate before birth and after death, as well as of the nature of eros, particularly insofar as the latter compels the soul to produce agalmata, or icons (252d) as effects of its ecstatic theophanic experience at the limits of mortal being. In the Book 
of Thoth, similarly, writing is understood as involving a kind of eroticism (or the alternate carnality of hunting; see Butler 2013, 225f.), and constant recourse is made to the production of images on diverse ontological registers, to the extent of the scribe's becoming "like unto a statue/sign" (B02, 8/10 [413]; Butler 2013, 227).

With respect to this becoming-sign the Egyptian meditation on writing seems to go further than the Platonic inquiry. The aspiring scribe, in order to pass from reader to writer, becomes a sign as a condition of assuming his place as a voice in the ongoing tradition, which I have argued, in the Book of Thoth is the intersection of three continua. First, there is a material continuum of textual traces, which for the Egyptian scribe is the marshland of reed pens and papyrus scrolls, on the one hand, and the ink made from charcoal, on the other; in the Phaedrus, the perspective of which is admittedly more oral, this plane seems to be manifest in the strong concern with place. Place becomes the marker for a relation to tradition when Socrates insists upon locating the myth of Boreas and Oreithyia correctly, which means in connection with the altar of Boreas, the living cult informed by the myth and which informs it in turn; and it is this insistence upon the living and spatial bond between myth and cultus that elicits Phaedrus's skeptical surprise. But further on, Socrates discovers the sacredness, too, of the place where they are, "a sacred place of the Nymphs and of Achelous" (230b), which occasions Phaedrus's remark that Socrates is like a stranger, rather than a native (230c-d), for Socrates has uncovered the generativity of place. Hence it is not merely a matter for philology of a one-sided subordination to an existing tradition, of cinerary traces, but of a living flow of new production, of the proliferation and diversification of tradition.

The second plane of textual formation in the Book of Thoth is a psychic continuum of voices in concord and disputation, which is the space, too, of Platonic dialectic and antilogikē, of palinode, of "sin" and "purification" (Phaedrus 243a-b). The forces on this plane, which is marked by struggle in both the Egyptian and Platonic texts, are what the Egyptian text refers to as the $b A$. $w$, a polyvalent term that can refer to souls, to potencies, or to books and other images as manifestations of these. The third plane, finally, is a transhuman continuum of prophecy, represented in the Egyptian text by the "speech" of sacred animals. We see this directly expressed in the locusts as angeloi of the Muses at Phaedrus 259c, but it is more importantly present in the dialogue's account of eschatological theophanies, in which the experience of different Gods yields different modes of eros, which, returning to our guiding orientation toward philology and the theory of truth, we must understand as an irreducible diversity of hermeneutical dispositions toward texts.

This diversity is irreducible on two accounts. First, because every "human" soul has by nature, that is, by definition of what it is to be human, perceived real beings (249e); and secondly, but more significantly, because no God can be treated truthfully as an evil (242e). Thus Socrates demands as an inflexible criterion of interpretation that every God be conceived as "the best and most beautiful thing possible" (Republic 381c), which demands a polycentric interpretation of myth recognizing that conflict among Gods can only be understood as involving conflicting goods. It is this, and nothing like the "boorish wisdom" of the demythologizing sophists (Phaedrus 229e), that leads Socrates to question a literal interpretation of theomachy in the Euthyphro $(6 \mathrm{a}-\mathrm{c})$. This irreducible diversity, in turn, because it is not unlimited diversity, prevents the existential privilege afforded every soul qua human from provoking a collapse into relativism. The principle embodied in the polytheistic and polycentric formation of this theophanic plane 
not only preserves the Gods, with each a unique and distinctive truth-preserving total perspective, from being written out of the text in favor of some singular totalizing perspective; it also urges, albeit with less force, a generalized hermeneutic of charity, such that "the word which the wise speak not be rejected, but we must see if they are right" (Phaedrus 260a, quoting Iliad 2.361; trans. Fowler).

Each of these three planes can expand to account for the entire domain of textual phenomena, which may accordingly be read materialistically, psychologistically, or theophanically in toto. The Phaedrus, by contrast, marshals all its resources toward a single, sustained argument against sophistical mock-philology: that the philologos must attend to what ought to be said, and not merely the rhetorical form of the text (234e); that regarding form, it is to be studied for the purpose of distinguishing what is "inevitable" in the text from what is "invented/discovered" (236a), the probable or mere descriptive regularity (272e) from the activity of principle; that philology cannot be a merely technical exercise, but must "seize hold of truth" (260e), which includes maintaining its connection to cosmological "high speculation" (270a) as well as to the rapture (harpazein, 229b) of prophecy. It is, finally, the integrity of the soul that ensures the integrity of the text (264c), and vice versa; true rhetoric, that is, philologia, is a psychagogic techne (261a) whose ultimate orientation is toward pleasing, not humans or power, but the Gods (273e-274a). The integrity of the text and of the soul secure one another because "serious value" is found "in words about justice and beauty and goodness spoken by teachers for the sake of instruction and really written in a soul" (278a; trans. Fowler).

\section{From philology to philosophy: Plato, Nietzsche, Classics, and The Nay Science}

Acknowledgement: This essay was written by John R. Lenz, Drew University.

The Nay Science (Adluri and Bagchee 2014) is a manifesto for the humanities, couched as a critique of Indology. It is a critical history that says that wisdom does not depend on history. The work carries many implications for my field, Classical Studies, and for the present and future of education. I will focus on three places where the authors reveal their purpose, namely the Prologue, the last pages of Chapter 5 , and the Conclusion.

Over this work hover Plato and Nietzsche and others such as Heidegger. With them the authors point both backward and forward to the ancient Greeks. Plato coined the words "philology" and "theology" both (as far as we know). These terms are mutually entangled for him and for Adluri and Bagchee who proffer a Platonic paradigm for philology ${ }^{3}$ as pedagogy for the human soul. The authors begin (Prologue) with a story (logos) about Socrates, who rejects the rationalization of myth by clever so-called wise men (sophoi). His love of logoi serves his quest for wisdom: words, speeches, dialogue, reasonings are all included in the meaning of the word; one logos is not enough, unlike in another famous ancient Greek text (John 1:1). ${ }^{4}$ While critiquing traditional stories (muthoi) Plato writes his own (logoi). The Nay Science is a long attempt to justify the value of thinking with ancient existential and metaphysical narratives.

Socrates' piety towards the mythic and divine (Adluri and Bagchee 2014, xiii), his "ultimate concerns" (416 n. 197, 435), set the tone for the study of literature in this book. The first villain is Phaedrus, a prototypical critic, the lover of a pedestrian speech (Lysias'), who later profaned the mystery-religion. Bad philology, which limits itself to realia, reflects bad religion (thus they paraphrase Socrates' dismissal of poor Lysias in Plato's Phaedrus). Adluri and 
Bagchee do not wish to call their own view religious, in line with some complex twentieth-century interpretations of Plato, yet they assume the immortality of the soul foundationally (xiv-xv, cp. 395, 440; below, n. 10). Texts that reveal Being are privileged here. These latter two points are problematic and too significant to slip in without discussion. Elsewhere, however, they admire the mortal soul (5). Ultimately the goal is an ethical life (xvi, 445). Socrates said, these ideals may or may not exist, but store them up in your soul as a model to live by (Rep. 592b). This respectful philology is a matter of life and death, namely philosophy (Adluri and Bagchee 2014, xii, 430).

Nietzsche's career inscribes the very turn from philology to philosophy that The Nay Science calls for. His Basel inaugural lecture, "Homer and Classical Philology," promised, "philosophia facta est quae philologia fuit" (Nietzsche 1909 [1869]), reversing Seneca's phrasing but in fact agreeing with the Roman sage who laments, "the study of wisdom has become the study of words" (Epistulae Morales 108.23). Nietzsche continued, "all philological activities should be enclosed and surrounded by a philosophical view of things." Similar pedagogical pleas of the kind that motivate The Nay Science (and its punning title) animate his lectures on education (Nietzsche 2016 [1872]) as well as the unpublished notes for Wir Philologen (Nietzsche 1995) ${ }^{5}$ :

[T] oday's teachers ... proceed ... so textually and historically that at best they might turn out some more little Sanskritists. ... Historical, in fact philological, considerations have slowly but surely taken the place of any profound exploration of the eternal problems. (Nietzsche 2016 [1872], 47 and 78) ${ }^{6}$

[T] he scholar ... [lives only] as a forerunner of the philosopher, who knows how to use the scholar's ant-like labor to express an opinion on the value of life. ... 'Your own salvation matters more than anything else'-we should say to ourselves; and there is no institution you should value more highly than your own soul. ... like Socrates. ... The scholar must be a scholar from self-knowledge .... (Arrowsmith 1973/74, 3[63] and 3[69]) $)^{7}$

For Nietzsche, as for Adluri and Bagchee, classic texts exist for us, for our life, creativity, and emancipation, not we for them. This has been called "existential philology" (Young 2010, 156-57). "What do you do with Homer?," one scholar asked another. No: we need Homer more than he needs us. "The Greeks are in front of us" as beacons. ${ }^{8}$ Nietzsche recognized the hard work needed to free our appreciation of antiquity from Christianity (Arrowsmith 1973/74, 3[13], 5[5], 5[15], 5[16], and elsewhere). And so with the Indian epics.

Nietzsche wrote, "the essence of religion consists precisely ... in the power to create myths" $\left(1995,157\right.$, Notebook 27[1], undated entry [Spring 1873]). ${ }^{9}$ This applies to Homer, the Bible, Plato, the Mahābhārata (cp. Adluri and Bagchee 2014, 408-9), Mormonism, and some twentieth-century thought on myth and narrative. This is an acute thought about religion, but it does not give us license to revere all received tradition. In the present work the unsolved problem remains of how to proceed from mythic narrative to an argument in defense or advocacy of religious meanings found in traditional texts. The last chapter of The Nay Science concludes with Heidegger's call for "a return to the Greeks" (431). What a return of the Greek gods means (430), or a "theophanic vision" (432), remain as portentously unclear as Heidegger's creative etymologies. Such ultimate matters deserve more explanation (along with two others I noted above). Again, more positively, we see that philology (made 
philosophical) and the concerns of theology merge, when we approach and receive the existential import of ancient wisdom; but not in the text-historical way the authors ascribe negatively to Protestantism. The Nay Science argues passionately for the rationality of such wisdom: the "divine eye" the Indian god endows the hero with is (they hold) reason. ${ }^{10}$

One can disagree about theology (as above) and other points: Persephone did not conquer death through love (xii). Is Heidegger correct about the alleged original meanings of the words verum, falsum, and aletheia (430-31)? However, beyond these debates, significant implications follow for the humanities and for my age-old field, Classics, and for education itself.

The text-historical dissection of Homer by F. A. Wolf (1985 [1795]) is considered the canonical origin of modern philology. The eighteenth century made Homer safely remote: the patchwork, corrupt text, composed for its own age(s), and therefore (allegedly) not for all time, did not threaten (but its discovery reinforced) the victory of modern knowledge in the "ancients versus moderns" debate. "German philologists ... replaced classical models of moral authority with the authority of the modern philologist" (Reitter, Paul and Chad Wellmon in Nietzsche 2016, 115 n. 9). The Nay Science shows how to deconstruct this paternity-claim of philology, which emphasizes the technical at the expense of the humanistic and even precludes a deep reading. Indeed, I would look to Wolf's and others' humanist writings (rather than any supposed technical or methodological advances) for what he and other "founders" thought was important in the present about the study of ancient works: generally speaking, Bildung or one's development as a human being. Nietzsche himself, while savagely criticizing professional philology, extolled (separately) Wolf's humanism. ${ }^{12}$ He and The Nay Science both demonstrate that these are two divergent paths; the one (humanism) does not follow from the other (text-historical philology). Please re-read the previous sentence; this is the book's most important contribution. This crucial point remains urgent today.

Enduring works reflect on human existence. Philology has banished thought because it assigns it to another discipline for other people called "philosophy." Latinists study Lucretius as a poet not a sage; that is safer (Lenz 2011). A popular book (Romm 2014) presents Seneca as politician not a philosopher. ${ }^{13}$ Clearly, the writing of popular books does not cure the problem with academics. Uncomfortable with Classical moralizing and uncertain about meaning and tradition (understandably), we yet go too far; we avoid meaning and we lose the value of thinking with wisdom literature. The move from philosophy to history is well established. Religion is not talked about yet is taken for granted. A best-selling book makes Jesus a politician without talking about religion at all (Aslan 2013). ${ }^{14}$ This reveals a lot about modern academics ("all is politics"). Similar limitations bedevil studies of Socrates and of ancient Greek religion (two topics where more work could be done on Christian supersessionism, as Simon Price has shown for Delphi). ${ }^{15}$ Identity politics and social sciences dominate the humanities. As an antidote, The Nay Science and recently William Deresiewicz (2014, 112 and 200) advocate soul-making education. Nietzsche did not find this in universities either: "Criticism of the philologist. The value of the ancient world: it sinks with you. How terribly you must have fallen, since it has such small value now!" (Arrowsmith 1973/74, 3[62]; a similar sentiment is expressed in Nietzsche 2016 [1872], 45.) The Nay Science reminds us what the humanities should be: the ethical education of the self, with awareness of mortal human existence in the cosmos. In short: even scholars need to use books to change their lives; and if they don't, who will? 


\section{The Nay Science and the history of philosophy}

Acknowledgement: This essay was written by Antonio Luis Costa Vargas, Humboldt Universität zu Berlin.

"Philosophers do not understand each other" is a common result of historical research. Again and again, close studies of one philosopher's reception of another show that he read his fellow philosopher according to his own interests, ignoring what questions originally motivated the author. Philosophers have shown themselves to be untrustworthy readers of texts. This is especially the case when philosophers have rallied around a banner: who will trust a Neoplatonist reading Plato or a Neothomist reading Thomas? The very commitment to a philosophy renders one blind to its uncertainties and to the contingent circumstances it arose from. The interpretation that arises in such philosophical traditions is a suspect hybrid of history and philosophy. In contrast, an ascesis is required in the history of philosophy, a systematic suspension of one's own burning questions to understand another thinker on his own terms. Learning this ascesis and learning how to ask the "right" questions of a text, to understand not only what it means, but also what its author meant to do by composing it, is the essence of training to work in the history of philosophy.

But is such a distrust of philosophers in the understanding of philosophy a result of historical inquiry or a presupposition of its methods? This is the question that someone working in the history of philosophy will have to ask themselves after reading about the catastrophe of German Indology in The Nay Science. The question will have no universal answer: different historians work in different ways, and each person will have to account to themselves for his own manner of reading. But no one can remain indifferent after learning of the epistemological monsters that reason gave birth to in the narrow, positivistic, "enlightened" minds of the Indologists described by Adluri and Bagchee. To what degree do we in the history of philosophy not approach our texts in a manner analogous to the Indologists, leaping over traditional reception in order to find some historical "core," "what the authors really meant" as opposed to later "spurious" systematizations and developments?

This is not, as Adluri and Bagchee show, merely a matter of our own self-consciousness. The Indologists in their double ignorance unwittingly carried out an originally Christian project of delegitimizing the hermeneutic traditions in India that read the Bhagavadgitan and other texts with soteriological concerns. Furthermore, they stalled any creative philosophical reception of Indian texts in wider German culture. To what degree does our own practice of the history of philosophy in an analogous fashion, instead of making a fresh reception of past philosophers possible, delegitimize a properly philosophical engagement with the texts, by insisting that narrow historical questions are the only proper questions to put to a text, and that to go to a text motivated by one's own philosophical interests is a sure guide to misinterpretation ${ }^{16}$ And if we do find our studies to be philosophically counterproductive in this matter, perhaps we should investigate another suspicion raised by Adluri and Bagchee, namely that perhaps the study of past philosophy is valued in part because of the identity it gives to the scholar, as the member of a more enlightened age, equipped with subtler logical tools or more cunning hermeneutical suspicions than the naïve past.

For the study of ancient philosophy, the shadow that Christian concerns project over Indology may be most interesting. Adluri and Bagchee detail how a number of Protestant concerns (Luther's attack on the theologia gloriae, the certitude of salvation through faith, suspicions of the pantheistic nature of reason arising from the Pantheismusstreit, 
the oppposition between the universal priesthood of the faithful and the existence of a ministerial priesthood) deformed a reading of the Bhagavadgitā by giving rise to a particularly narrow conception of reason and what it could achieve. As the study of ancient philosophy moves past positing oppositions between what is "philosophical" and what is "religious" or "mythical" (not to say "superstitious") in ancient and late ancient philosophers ${ }^{17}$, in order to cement such advances it may be useful to lay bare the Christian roots of the narrow conceptions of reason that are now being overcome. ${ }^{18}$ These roots are of course not only Protestant. Indeed the effort of Catholic theology to separate out the respective contributions of the light of natural reason and the light of faith, conceiving of natural reason as what was shared by pagan and Christian philosophers and as an autonomus human faculty in contrast with the gift of faith, may plausibly be seen as roots for the view of philosophy as an autonomous activity with respect to myth and religion in the ancient world. ${ }^{19}$

At the end of The Nay Science, Adluri and Bagchee present Gandhi's interpretation of the Bhagavadgitā as an alternative approach to texts, one that recognizes that "there can be continuous inflation in the use of words and yet their essential meaning is preserved", such that the questions asked are not narrowly historical but relate to ever present ultimate concerns. In order to generalize this example, it is useful to observe that Gandhi supports his interpretation by the status of the Bhagavadgitā as the work of a poet: "Because a poet puts a particular truth before the world, it does not necessarily follow that he has known or worked out all its great consequences or that having done so, he is able always to express them fully" (Desai 2009, xxiii). "In this perhaps lies the greatness of the poem and the poet. A poet's meaning is limitless" (xxiii). Thus a special kind of interpretation is warranted for a special kind of text, poetry. This points to a task required in order to ground this approach: it is not enough to point out how the identity of a text is in part constituted by its reception, as B\&A do, following Gadamer; what is also required is an account of the peculiar kind of intention whereby human agents can will and intend a content that is not in their cognitive control, but which they nonetheless aim at. Here again, Plato, with whom Adluri and Bagchee begin their inquiry into philology, is key. For what are the desire for the good, the pursuit of wisdom, the love of beauty guided by Eros if not intentions that surpass every cognition of those that venture on them? Plato thus first posed the question of such indeterminate intentions that are able to found a tradition and are correctly interpreted only within a tradition. The primordial example of such an action is the care of a family, as Gandhi explains: "We shall do no injustice to Vyasa's words by expanding their meaning. Sons should enlarge the legacy of their fathers" (39-40). And indeed, perhaps the narrowness of our histories ultimately rests upon the narrowness of our desires: do we care for our family as a tradition of nature, stretching back to our ancestors and forward to our future relatives, or do we care only for our immediate, nuclear family? Do we pursue the good as such, or only particular goals that we can be successful in achieving? Do we seek wisdom or only answers to highly specific, technical questions? Not only our interpretations, but our rules for interpretation should be verified in our lives.

\section{Perspectives from a graduate seminar reading of The Nay Science}

Acknowledgement: This essay was written by Doug McGetchin, Florida Atlantic University.

These remarks incorporate responses to The Nay Science (Adluri and Bagchee 2014) as a text in a graduate class at Florida Atlantic University. ${ }^{20}$ The key critical issues that emerged were questions about how the work fits into its geographic and temporal context and 
potential problems with the validity of the project itself. The central focus that emerges clearly is the racist and religious misuse of Indian texts by German Indologists. Adluri and Bagchee argue persuasively for the damage the Germans caused to Indian cultural heritage in the German Indologists' approach to the texts, ignoring the Indian commentarial tradition and forcing their own religious and cultural concerns on the Indian epic.

The main focus of the study is a close critical reading of important Indian texts such as the Mahäbhärata and the Gittā and critical analysis of their interpretations by a few key Indologists, Adolf Holtzmann Senior and Junior, Christian Lassen, and a few others. Regarding the scope, given the choices of breadth versus depth, the narrow focus was needed, as to make their case the authors needed to do a deep dive into the specific material and not explain their subjects' connection to the larger context in great detail. While the problematic patterns the authors identify-distorting ancient Indian texts to fit the needs of modern Germans-would apply throughout large sectors of Indology, their defenders might ask, how representative were the figures the authors examine? What countercurrents and other structures make up the landscape of German Indology? There were different schools of Indology at Bonn, Berlin, Tübingen, and others. The next steps would involve situating Holtzmann and the figures the authors examine within a wider brush of German Indology. Casting a wider net, to Königsberg, for example, the work of Nick Germana, The Orient of Europe (Germana 2009), would provide a more complete picture. One wonders how prevalent the theories postulated by early German Indologists were in the greater German society. Furthermore, how did Germans fit with other Indologists in Europe? The Nay Science also leaves one wondering about a transnational comparative approach such as Dorothy Figueira's in Translating the Orient (1994), comparing German and French nineteenth-century translation conventions.

This wider scope would provide nuance that the book does not fully consider, for example, in the difference between continental Indology and that practiced by Max Müller, a German émigré to England, and his associates, who did make an effort to take into account Indian commentaries and grammarians like Panini. Those in Müller's orbit were much more intimately connected to India and Indians; Georg Bühler traveled extensively in India collecting manuscripts and Martin Haug was a professor at Poona college, for example. Although Müller himself never went to India (as he said, lest he lose himself in love with the place), many of his students and fellows in his school did go there, albeit in the service of the British colonial masters. Müller's proIndian methods alienated him from the "triumviri" Albrecht Weber of Berlin, Otto von Böhtlingk of St. Petersburg, and the American Yale scholar William Dwight Whitney, Müller's nemesis. Whitney hated Müller and Bühler for being "the mere mouth-piece of Hindu grammarians." So there are wider European counter-currents to the main image Adluri and Bagchee portrays, although perhaps even the Müller faction was an exception that proves the rule The Nay Science examines.

One student moved to deconstruct the deconstructive aims of the book itself, pointing out that Adluri and Bagchee are doing to the nineteenth-century Germans what Holtzmann was doing to the Gittā, refashioning it in their own image. Is such a reconstruction necessary? The authors would I think answer, why would one want to leave an error uncorrected? A greater problem would be to knowingly leave the problem unaddressed, thus compounding it. A surprising element is the conclusion and the use of Gandhi as a foil, seeing the text as a postcolonial critique of Eurocentrism. Instead of Gandhi, why not an Indian commentator from the nineteenth century or earlier? 
Adluri and Bagchee should be applauded for greatly expanding the range of works delving into German Indology. Nietzsche in On the Advantage and Disadvantage of History for Life wrote about the need to go beyond hagiographic hero worship and an antiquarian collection of mementos, which in the field of German Indology are the diplomatically sanitized and deNazified biographies by Valentina Stache-Rosen (1990) and the internal history by Ernst Windisch (1917-20) compiled after the First World War, a self-referential discipline history by an insider for insiders tracing lines of development completely absent any larger cultural or social references and criticism. Hamburg Indologist Albrecht Wezler (1993) has called for such a critique in 1993 in Studien zur Indologie und Iranistik and Adluri and Bagchee have delivered.

I wonder if Adluri and Bagchee have delivered too much for some to handle, a whirlwind. Their tone is critical, occasionally even acerbic. Taking a page from Nietzsche, they criticize the Indologists' exploitation and abuse of the German university system. Indeed, more than the consequences of Indology for Indian texts, their book is concerned with the legacy of Indology in its privileging of positivistic philology over pedagogy. Such an approach will and has put German Indologists on the defensive, as they probably should be. But the goal of the book, the authors explicitly clarify, is to call Indologists to account by the selfsame standards of objectivity, impartiality, and universality to which they themselves appeal. Reflecting on the furor of Edward Said's Orientalism (1978), German Indologists are a much smaller target, less momentous in the West. The legacy in India remains extensive, however, with much more at stake than a minor discipline in Germany. Germany's Indological reach within the Indian subcontinent, in constructing Indians' ways of thinking about themselves, as filtered through Europe, is still vast-see Dipesh Chakrabarty's Provincializing Europe (2007). Defenders of the status quo of German Indology and the Western canon seem to have much to fear, but what is the worst that could happen? Open their field to Indians and to questioning and "native" criticism? They would have to digest an infusion of new ideas, and upset existing patterns. The Nay Science is a dangerous storm, but needed to clear away centuries of unexamined and pernicious underbrush. Perhaps this is what those resisting examining the roots of German Indology fear, that some housecleaning will bring down the entire structure. Not every Perestroika leads to the fall of a Berlin Wall, however. Kali Ma transforms as well as destroys.

\section{The significance of The Nay Science for the study of the Mahābhārata}

Acknowledgement: This essay was written by Bruce M. Sullivan, Northern Arizona University.

The Nay Science (Adluri and Bagchee 2014) is a brilliant work on the history of Indology as a discipline, particularly as conceived and executed by German scholars. As a history, this work is retrospective, providing extensive documentation on how Indologists have approached the Mahābhārata, and includes a chapter (156-313) devoted to scholarship on the Bhagavadgitā. As the authors state,

... the scope of our inquiry was delimited by its double concern of presenting a history of German Indology from the perspective of its method and a history of its method from the perspective of its theological inheritance (the two, in the end, being one and the same). (19)

One distinctive feature of the method here examined is an analytical approach to textual analysis in which the Mahābhärata is deemed to have multiple authors contributing to the text over many centuries. As Adluri and Bagchee observe, "a basic presupposition for their research was an ability to distinguish between an original warrior epic and a later bhakti- 
colored Brahmanic text in the Mahābhārata" (443). Table 3.1 (309-12) shows the result of such an analytic technique regarding the Bhagavadgitā, in which seven scholars, each positing a different vision of what was "original" to the text and what was added in successive layers, reach different conclusions as to what should be regarded as this text's core, and its original meaning. These scholars do not agree with each other, so their method does not result in a set of findings on which to base an understanding of this text. Indeed, the approach reaches its logical and absurd culmination with the publication in 1969 of Georg von Simson's study that elides the text entirely, leaving nothing at all as "original."

As argued by Adluri and Bagchee, textual interpretation is difficult, requiring "qualities such as patience, sympathy, maturity, and intellectual and personal humility. In contrast, so-called 'layers analysis' (Schichtenanalyse or, as it is also called, Textenschichtung) takes only a little sophomoric skill" (444). They translate the "classic statement of the principles of this method" by Paul Hacker from 1961, which includes the following pronouncement:

... at first, one contemplates the transmitted works not as a whole, but rather dissects them in pieces that are coherent in terms of their content ... and looks for pieces that correspond partially, whether literally or in terms of their content, either in other works or in other contexts of the [same] work; one compares these and then develops the procedure of comparison each time from the realities [Gegebenheiten] of the text. (Hacker 1961, 489, cited in Adluri and Bagchee 2014, 444, n. 36)

The image of textual dissection (or perhaps vivisection would be a better term) suggests something further about the method described so clearly by the well-named Professor Hacker. The text having been rendered into disconnected pieces, the idea of interpreting its meaning seemingly lost in the process, one now looks outside the text for correspondences that might facilitate understanding of the formerly whole text. In the spirit of comparison, one might see in such a method the approach taken by museum curators who, in their effort to exhibit a dinosaur, supply missing bones from some other skeleton to complete the exhibition. The subjective judgments regarding what might constitute coherence, and where the layers are seen to be divisible, accounts for the diversity of findings by scholars trying to utilize this method even on a relatively short text such as the Bhagavadgitā.

A consistent feature of the "historical-critical method" is that diverse modes of discourse within a text are regarded as due inevitably to a multiplicity of authors, and that these authors are contending with each other for control of the text's contents. As Adluri and Bagchee note, because the method is "essentially dialectical in nature," it assumes a "minimum of two redactorial agencies or ideologies in the text." Once this difference is posited "in order to observe it (in the form of "scientific" propositions)," the method then permits scholars to "recover the part one had all along been interested in" (17-18). (The method is discussed also on 150-51, n. 240; and 318.) In the case of the Mahābhārata, bards associated with the warrior class are regarded as having originated the text but lost control of it to Brahmins, accounting for the diversity of content and style of discourse. Beginning with Christian Lassen (1800-76), continuing with the Holtzmanns, and into the twentieth century with E. W. Hopkins, "layering" as the only explanation for the growth over centuries of the Mahābhārata became such as well- established idea that the absence of evidence for it was rarely questioned (see especially the charts summarizing findings throughout chapters 2 and 3). As a counterexample of a text from more recent times with a marked diversity of discourse styles and content, I cite Herman Melville's Moby-Dick (1851). The novel has two very different types of material: an action-filled narrative concerning an expedition to hunt whales, and 
information about whales that is encyclopedic in scope, ranging from mythology to anatomy. Indeed, the text refers to the white whale as Viṣnu's avatar (Sullivan 2001). These two very different styles of discourse, profoundly divergent in content, we know to have been written by the same author in a frenzy of creative activity in mid-nineteenth century New England, based on letters between him and his correspondents (such as author Nathaniel Hawthorne). We need not imagine some other author elbowing Melville away from his desk and executing a hostile takeover of his manuscript to add material-such as whale lore being interpolated into the existing narrative. As we know from other sources, this text was not produced by layering new material on old. Nor need we imagine a similar hostile takeover of the Mahābhārata project by ideologues intent on imposing an alien theological vision on what had been a rousing tale of warrior heroism. Theological meanings are central to the text, as indicated in various works including my own (Sullivan 1990).

The significance of The Nay Science for the future direction of Mahābhārata Studies lies in its accomplishment of showing the failure of the "historical-critical method" and its subjective approach to analysis of the text by an imagined layering of the text over time by competing authors with differing ideologies. Were the failings of the "historical-critical method" of only antiquarian interest, we could ignore them, but because this approach to the text is still seen by some scholars as viable and even the preferred method, its shortcomings in regard to Mahabhärata Studies needed to be clarified. As Adluri and Bagchee demonstrate, the theological presuppositions of German scholarship on the Mahābhärata belie its claims to objectivity and impartiality, forcing us to rethink what it means to study the epic. Clearing away this failed approach, to which The Nay Science contributes greatly, allows new approaches (such as in Argument and Design, Adluri and Bagchee 2016) with a greater value due to their greater likelihood of helping us to understand this text. We are now in a better position to understand how and why Hindus have seen coherence and meaning in the text, understood it to have communicated profound insights, and therefore regarded the Mahābhārata as both a foundational text for the Hindu religious tradition and one that remains to this day relevant to Hindus.

\section{Applying the hermeneutics of suspicion to the hermeneutics of suspicion}

Acknowledgement: This essay was written by Jeffery D. Long, Elizabethtown College.

In their important and controversial work, The Nay Science: A History of German Indology (Adluri and Bagchee 2014), Vishwa Adluri and Joydeep Bagchee level powerful criticisms against German Indology. These criticisms are particularly pointed to the degree that the assumptions and methods that are their target continue to be held and practiced by many whose profession involves the study of Hindu texts and traditions.

One very central scholarly stance that Adluri and Bagchee critique-central to their work, and to scholarship on Hinduism and religion more generally-is the hermeneutics of suspicion. At its most basic, the hermeneutics of suspicion is an interpretive stance that takes for granted that a text is not really about what it claims to be about, but is, rather, to be studied as revelatory of realities external to itself. "Such a hermeneutics," the authors rightly observe, "might justly be considered one of the founding intellectual gestures of our age." Such an approach, they also note: "appears, initially, to be incomparably more sophisticated than a straightforward reading of the text." "Yet," as they say, "one of the inescapable consequences of the hermeneutics of suspicion is that it 
introduces a disparity between the critic and the text" (299). It should also be pointed out that this disparity involves power, for the text is not in a position to "talk back" to the critic, to challenge the critic's assumptions. It is an object, which the critic is free to contextualize in any way he or she sees fit. In the words of S. J. McGrath, whom the authors next cite,

A hermeneutics of suspicion is necessary when reason is not in command of the discourse but is the product of 'false consciousness.'....In the Freudian model the analyst and the analysand are not on an equal footing. Assuming that the analysand is lying both to himself and to her, the analyst is primarily concerned not with what the analysand says but with how he says it...The relation is non-dialogical, or one-sided. The analyst gives little of herself to the relationship while the analysand must be trusted to hold nothing back if the cure is to work... The analysand is on trial; his language is not taken at face value. He is denied rationality, the ability to say what he means and mean what he says. His discourse is interpreted in light of assumptions that the analyst makes without telling him; his narrative is understood in terms of unconscious motives that are assumed to be revealed and concealed in the way he speaks or refuses to speak. (McGrath 2008, 4-5; cited in Adluri and Bagchee 2014, 299).

Such a stance, as Adluri and Bagchee point out, is practically definitive of modern critical scholarship. It is probably safe to say that it is a stance that was inculcated into all of us who study religion professionally. Before I proceed further, I should also point out that it is a valuable stance, a vital element in the scholar's intellectual repertoire; for texts do reveal much that they do not intend, and placing a text in a critical framework-whether that text is the Bhagavad Gitā or the Bible or a Jane Austen novel—can often tell us much about the social, cultural, political, economic, technological, and psychological factors that have gone into its creation. This is not to say that all such revelations are of equal value. Some, indeed, may appear ludicrously superficial from a perspective that is more richly informed by the self-understanding of the text in question. But they are not invalid. Each has its place in the larger realm of knowledge to which all scholarship aims to contribute.

The flaw, though, which can plague such methods, and which Adluri and Bagchee highlight, is a deficiency of self-critique. In regard to German scholarship on Indian texts they claim that, "although every German scholar set out from the assumption that Indian texts were corrupt, no scholar actually tried to demonstrate in what way this was so." On the contrary, in regard to the Bhagavad Gitā, "German Indologists went out of their way to evade an engagement with the Bhagavadgitā's philosophy...[T]hey in fact set aside the question of its truth-claims...The application of a hermeneutics of suspicion to the Bhagavadgitā had the effect of denying it any meaning or value and, above all, any philosophical or ethical dimension" (Adluri and Bagchee 2014, 300).

Again, it may be that not all scholars are interested in the philosophical or ethical dimensions of the texts that they study. A scholar interested in what the Bhagavad Gitā can tell her about chariot technology in ancient India will read the text differently than Mahātma Gandhi will. But this is not Adluri and Bagchee's point. Their point, as I see it-and it is an important one-is that in an environment where the "sophisticated" stance of the hermeneutics of suspicion is privileged over the "naïve" reading of a text as saying what it seems to be saying, the philosophical and ethical conversation is impoverished; for an important source of potential insight is removed as irrational, as a product of false consciousness, without any argument or evidence being offered to support this view other than the prejudices of a particular class of society.

Interestingly, Adluri and Bagchee show us that despite the antagonistic stance that is taken toward Hindu texts like the Bhagavad Gïtā by Christian missionaries, the writings 
of these missionaries show greater integrity by taking these texts seriously on their own terms "unimpeded by the secularization narrative the Indologists had in the meanwhile told themselves" (Adluri and Bagchee 2014, 300, n. 607). Part of this narrative is the delusion that the worldview of the critic is not itself a worldview among others-standing alongside, say, Hinduism or Christianity, and in as much need of articulation and defense as these others-but rather stands at an ironic distance from them, self-assured in its own merely assumed rational superiority.

The need of the hour, it seems, is a hermeneutics of inter-subjectivity, such as that proposed by Rita D. Sherma in her introduction to Woman and Goddess in Hinduism: Reinterpretations and Re-envisionings (Sherma 2011). The good work that a hermeneutics of suspicion is intended to do, revealing dimensions of reality disclosed in a text that are unknown or ignored by the text itself, can still occur in such an approach, but must be supplemented by an equivalent move of self-critique, in which the reader-who now becomes a participant in a dialogue rather than a detached analyst-allows the text to "read" her, to be engaged by its explicit claims and assumptions. Such a move has a number of advantages: placing the critic and the text on an equal level which allows for a mutual flow of insight rather than a dead, unidirectional didacticism, and, particularly in the case of religious texts, letting the community to whom the text is sacred stand in cooperative, constructive relationship with the scholar, rather than an antagonistic, suspicious one. Our relationship with those whose texts we study will often mirror that between the text and ourselves: friendly and constructive, or suspicious. This is not an irrelevant consideration in a place and a time wrought by religiously fueled conflict, and suspicion and hostility on all sides.

\section{Protestant presuppositions in the study of Hinduism}

Acknowledgement: This essay was written by Robert Yelle, Ludwig-Maximilians-Universität.

Let me say first that this is an important book, with a challenging and provocative argument. One reason why it is so challenging is that, if you take the conclusions of the authors seriously-and they draw all of the logical connections among the data, making it difficult to avoid their conclusions - then it appears that we are in a crisis in the study of Hinduism. Actually, the argument of the book has implications also for religious studies more broadly, inasmuch as it reveals the shaky presuppositions on which much of modern textual-critical scholarship, particularly but not only as applied to non-Western traditions, rests. Similar criticisms have been leveled at Western scholarship before. The complaint that European studies of other traditions express a bias toward the "original meaning" contained in textual form, a bias borrowed from the post-Reformation study of the Bible, is hardly new. What is innovative and impressive in Adluri and Bagchee's approach is the thoroughness with which they document the history and consequences of this bias at the heart of supposedly "scientific" (wissenschaftlich) German Indology in the nineteenth and twentieth centuries, as well as the extent to which individual scholars' reconstructions of the Mahābhārata and the Bhagavad Gitā were so variable, arbitrary, and tendentious. One is left at the end with a strong suspicion, or possibly even an unshakeable conviction, that elements of this bias continue, insofar as the method of disassembling and reassembling Hindu texts, irrespective of their received form and interpretation within India, in order to arrive at an "Urtext" continues, long after the separation of academic Indology from Protestant bible studies. 
I told the panel organizers that my comments would focus on Chapter Four, "The Search for a Universal Method." In this chapter, Adluri and Bagchee move away from specific historical discussions of individual German scholars, and articulate a number of basic and, to my mind, well-grounded claims. First, German Indology, even after its emergence from within Protestant biblical studies, remained a thinly scientized or secularized form of Protestant theology. This is not only because Christian theological presuppositions informed the particular reconstructions made by German scholars of Hindu texts, but also because the very practice of so rearranging these texts expressed a mode of relating to written scripture that had been developed after the Reformation. Second, the process of institutionalizing a hegemonic discipline of academic Indology in Germany reflected a bias, shared also with biblical studies, that Protestant modes of historical criticism were substantively identical with scientific method and consciousness. Third, both of these sets of biases depended fundamentally on a Protestant version of supersessionism, meaning the idea that Christian forms of knowledge had transcended and replaced older, less reliable forms of knowledge, a claim that was applied, both implicitly and often explicitly, against Brahmanism as it had originally been applied by Christians against Jews and pagans, and against Roman Catholics by Protestants. The appropriation of the authority to reinterpret, in wholesale fashion, textual traditions was not something that emerged only with the European discovery of India, although it derived a powerful impetus from that discovery. This appropriation was inherent already in the Christian designation of the Hebrew Bible as the "Old Testament." This required, from the early centuries of the Christian era, the claim that the New Testament revealed the "true meaning" glimpsed only dimly in the now-superseded Jewish tradition. A corollary of this was the claim that the Rabbis had falsified the texts, which accordingly needed to be rescued from their now-discredited custodians.

Adluri and Bagchee show how an anti-ritual and anti-priestly bias informed a number of reconstructions of the Gitā, such as Richard Garbe's notion that the original text "advocated the abandonment of sacred rites and placed no trust in the merit of works" (199). This expressed a Lutheran and more broadly Protestant conviction in the inefficacy of works to secure salvation. I have shown how similar ideas influenced the British interpretation of dharmaśāstra, as recently as J. D. M. Derrett's erroneous argument that the Gitā's idea of "bhakti" supposedly represented a recognition of the error of pursuing salvation through "works."

One name missing from the book's index, but which must be kept in mind in considering the phenomenon described by Adluri and Bagchee, is that of Julius Wellhausen. The reconstructions of the Gìtā done by Adolf Holtzmann and subsequent scholars were done after the triumph of the Graf-Wellhausen hypothesis, and presumably were influenced by it, at least indirectly. Wellhausen maintained a version of the "documentary hypothesis," or the idea that the Pentateuch or Five Books of Moses are not the work of one author, but a composite document, and were not composed in Moses's time, but redacted after the Babylonian exile. Wellhausen identified many of the ritual laws attributed to Moses as the priestly contribution to the Pentateuch, and dated these laws later than a number of other strata. The traditional assignment of many of these laws to Moses and to the period of wandering in the desert was therefore a fabrication or narrative fiction. To this historical reconstruction Wellhausen added a profound critique of the priestly tradition as a corruption and degeneration of an earlier, more natural form of Israelite religion identified with prophetic tradition, of which Christianity regarded itself as the legitimate successor. In this regard he followed and expanded upon 
traditional Christian condemnations of Judaism, particularly in its legal and ritual dimensions. The tendentiousness of Wellhausen's reconstruction has been noted by many, especially Jewish scholars, such as Moshe Weinfeld and Lou Silberman. Despite this, much contemporary biblical scholarship proceeds in the mode of footnotes to Wellhausen.

In light of the similar biases that German Indology inherited from Protestant theology, Adluri and Bagchee formulate the challenge thusly: "What kinds of changes might be necessary to the ways in which we engage with the ancient cultures of India as we move away from a Eurocentric Indology to a truly global, objective, and secular engagement with Indian philosophy?" (346) This is a question for the humanities in general, which our authors answer compellingly: "the rehabilitation of tradition must primarily take the form of a critique and, above all, of a self-critique of modernity" (355). Philological work goes on; indeed, must go on. Yet in light of the demonstration of the biases encoded in its ostensibly value-neutral methodological presuppositions, this work can no longer afford to be naïve regarding its own genealogy. Philology needs philosophy, or critique, both as prophylaxis against latent bias and in order to promote the progressive unfolding of historical consciousness, which is, after all, the goal of the human sciences.

\section{After indology: reading The Nay Science toward religious studies without Wissenschaftsideologie}

Acknowledgement: This essay was written by David Cerequas, Hunter College.

"As attention begins to focus on non-Western philosophies as an essential part of the global humanistic canon, the question is not 'whither the humanities?' but 'whither the humanities after Indology?"

-Adluri and Bagchee, The Nay Science

In the first weeks of an undergraduate course I teach on Modern Theories of Religion, students read J. Z. Smith's 2010 essay "Tillich['s] Remains..." (Smith 2010), along with John Thatamanil's response, and large sections from chapters 4 and 5 of Adluri and Bagchee's The Nay Science (Adluri and Bagchee 2014). Insofar as the scope of The Nay Science is read as being limited to the esoteric interests of highly specialized scholars invested in South Asian Studies and Mahābhārata philology, this grouping may seem odd. Students in this course, however, see no discontinuity of topic because, at bottom, there is none. The tragic flaw in this book then, as I see it, is that relatively few of those in its target audience seem capable of reading it as carefully as a couple dozen undergrads. Consequently, as crucial and timely as the content of The Nay Science may be for Religious Studies, the analysis it offers is not receiving the attention it deserves-and which we scholars need.

To review, it was Smith's claim that "Tillich remains the unacknowledged theoretician of our entire enterprise," and this he "intended as a double critique: first that the study of religion in secular public institutions should ground itself in a Protestant Christian theological project; second, that this influence should remain largely unacknowledged" (Smith 2010, 1139). Though it is a difficult observation to deny, in the limited space of that article Smith noted that a much larger inquiry would be necessary to thoroughly survey Tillich's-and 
thus Protestant theology's-influence on Religious Studies (1160-161). What Smith failed to recognize, however, was that the unacknowledged influence of "a Protestant Christian theological project" so pervades our discipline that traces of Tillich are only its most obvious signs. Adluri and Bagchee pick up the much deeper, and more troubling, intellectual and cultural conditions that would render Tillich's Protestant proselytizing (Tillich 2001 [1957], 113) acceptable to "secular public institutions."

An attentive reading of The Nay Science establishes, in great and careful detail, that even a total rejection of Smith's particular focus on Tillich should do little to alleviate the force of his underlying critique. For whether we trace the history of Religious Studies through Tillich or Eliade, Müller or Tiele, Parrinder or even-by creative anachronism-Megasthenes, the conclusion is the same: The Ursprung of Religious Studies is only either the Protestant or the Indologist (or both). In the case of the modern disciplines comprised by the American Academy of Religions, it is specifically a German evangelische Indologie that has shaped an overwhelming portion of our enterprise, especially as it relates to the dominant pedagogical language of undergraduate instruction. As a result, this indictment of German Indology, compellingly documented in The Nay Science, should be of concern for all who would engage the subject "religion."

Readings of The Nay Science also seem plagued by a tendency to approach it as if it were primarily a contribution to the corpus of post-colonial criticism. Though it could certainly be instructive for such work, Adluri and Bagchee refuse to indulge juxtapositions of etic and emic hermeneutics and eschew any direct analysis of colonialist power dynamics. On the contrary, the entire critique of Wissenschaftsideologie is performed from within, and with almost exclusive reference to, a decidedly Western philosophy-as evidenced by the whole of Chapter 5, the Introduction, and the titular reference to Nietzsche's work aimed at a similar target. In the sense of exploiting a decadence internal to the discourse, The Nay Science is more a work of deconstruction than post-colonialism. Let us beware, however, of casting it as yet another iteration of post-modernist antirationalism, since, here too, it exceeds the category and frustrates easy categorization.

Where post-modernists might curve their signifying chains into the question marks of a weak thought behind the veil obscuring some impossible future to come, Adluri and Bagchee elect to take the challenge of revaluation to its conclusion by positing new values to guide our work. And let us note that the return to "tradition" advanced in the last chapters is new. At work here is not some impulse of a reactionary nostalgia that turns us away from the world into which we are thrown. Instead, The Nay Science would turn us towards a more radical and invested rappochement with a traditionally integrated faith-and-reason "where rational soteriology was a real possibility, and where the texts explicitly claim to undertake the necessary pedagogy through rational means" (Adluri and Bagchee 2014, 421; my italics). This appeal to tradition is not about the recovery or reformation of dead letters but is "a matter of inheritance and its enrichment" (438) in the lived world. Here, "the what and why [of a self-conscious interpretive stance] are subject to ethical introspection and practice" (441).

The true problem facing the humanities today-and this is particularly notable in the case of Religious Studies-is the degree to which they have become divorced from the lived human concerns they were developed explicitly to address. In short, the vital issue of the humanities is the withering of its human vitality. Following on a detailed diagnosis of this wasting disease, based in an analysis of a prominent and persistent symptom, 
The Nay Science offers a deeply optimistic hope for convalescence. "The diremption of the text-historical method and the power structures built up on it," as Adluri and Bagchee note, "offers an opportunity for the humanities" (432). Although their immediate context might limit that opportunity to Indian literature and philosophy, I contend that its scope and import is much, much wider. After Indology, "every daring of the lover of knowledge is allowed again; the sea, our sea, lies open again” (Nietzsche 2001 [1887], \$343).

\section{The Nay Science and the future of philology}

Acknowledgement: This essay was written by Na'aman Hirschfeld, Humboldt Universität zu Berlin.

Vishwa Adluri and Joydeep Bagchee's The Nay Science: A History of German Indology (Adluri and Bagchee 2014) is the result of a truly collaborative study, which is a rare thing indeed in the humanities. This collaboration is evident in the admirable vastness, depth, and erudition with which the book is composed, as well as in the transcendence of disciplinary boundaries.

While the authors do not make this connection themselves, the work's project should be viewed in my opinion relative to that of the "Future Philology" that Sheldon Pollock called for in his seminal article (Pollock 2009): it is not envisaged as merely another history of German Indology during the eighteenth and nineteenth centuries but rather as a "disciplinary-reflexive" critical-historiography of the "textual-historical method" that focuses on, analyzes and criticizes several different interpretations of the Mahābhārata and the Bhagavadgitā and through these offers a unique perspective of German Indology qua an interpretative tradition (see Adluri and Bagchee 2014, 4-6). Using this approach, which shows how alternative traditions of interpretation ("other philologies" to paraphrase the authors) were suppressed by the workings of "science" (which, as the authors show in a remarkable way in the fourth chapter of the work, remained highly theological notwithstanding its claim to "secularity") the authors aim at a critique of the scientificity of this method, clearing the way for the possibility of a theorization of (re)newed scientific-hermeneutics and philological practices.

This is the main topic of the fifth and final chapter of the work, in which the authors treat the question: "in what sense is text-historical research a science?" (413) by discussing its scientificity relative to positivism, historicism, empiricism and criticism-relative to which it is found to be wanting. Although the authors offer a very intriguing reading of each historical phenomenon, the authors' treatment of German Indology in this chapter is highly problematic because it treats it as a single phenomenon, intentionally blending the contemporary (late twentieth century) and historical (eighteenth to early twentieth centuries) moments of German Indology and effacing the boundaries between them. This introduces an ironic tension into their interpretation since they come dangerously close to duplicating the "scientific" operation they set out to criticize when they establish the veracity of their own (present) discourse through its differentiation from that of a corpus that is found to be "un-scientific" and in need of correction.

Furthermore, although this strategy works for much of the book, as far as it works to "break up the monolithic narrative of an enlightened non-political, non-ideological science" (6), it derives from a formulation of the project that posits it in the following terms: "if one can at all speak of a telos here, it is a negative telos: we do not explain how the discipline arose, but how it ended. Thus, it is really the dispersal or diremption of the text- 
historical method at the end of the twentieth century that interests us" (6; italics in the original). This results, in my opinion, in an inability to contend with one of the core questions posited in the introduction-"How did a method that was radically theological in its origins capture the imagination of Sanskritists around the globe and become identified with the ideal of objective, scientific investigation into Indian texts tout court?" (6). Simply put, the above formulation introduces a strong contemporary bias for which the authors fail to account, leading to an anachronistic judgment regarding the scientificity of nineteenth-century German Indology that is decontextualized to a large extent, which enables the simple, even simplistic assertion that it was "not-scientific."

Although this approach is necessitated as a way of criticizing the still prevalent remnants of the "textual-historical method," regarding historical German Indology I will promote the following argument in contrast to that of the authors:

(1) German Indology was a science because it was accepted as such within what we can understand as the prevalent (western) truth-regime or discursive formation (to employ Foucault's terminology) of its respective time, especially in the latter nineteenth century, where it enjoyed for a time a privileged position.

(2) Therefore questioning its scientificity as valid or invalid is an unhistorical treatment; one should consider the sociocultural and discursive realities of knowledge production of the time.

(3) Given these one could assert that this science served wide ranging and even vital cultural functions by studying the "degenerated" Indian orient, which was posited as an origin, thus equating the Germans in particular and the "Aryan" West in general with cultural cohesion.

In this regard it should be understood in terms of what Michel de Certeau (1988) defined as a Hetherology or a "science of the other," which using the procedures and operations of science produced the identity of the self out of the "unintelligible" other (see especially 1-18 and 56-112). Here the very utilization and deployment of scientific terminologies and nomenclature, as well as what de Certeau so brilliantly described as the "historiographical operation," namely, the apparatuses of knowledge production that support and define it (the state, the public, the university system, etc.), posited Indology as part of a larger a knowledge industry within which it enjoyed a privileged place-for a short period of time. All of these do not detract from it being a science, but on the contrary, they are based upon it. What changed is the times. Our understanding of science and the scientific paradigms themselves changed, but that is the nature of the history of science: things are not fixed, and to judge the science of the past in accordance with our contemporary understanding is anachronistic. Of course, late-twentieth century German Indology also exists in a vastly different scientific landscape from that of the early twentieth century or late nineteenth century, and the critique leveled against it might well be deserving in this regard. But the blending of the different historical moments here is not justified as a historical procedure and it weakens the overall critical drive of The Nay Science in my opinion.

Yet with the above criticism in mind I would like to conclude by saying this: The Nay Science is an ambitious study that offers a unique vantage on the history of German Indology in particular and German philology in general with an almost encyclopedic level of detail. Not less importantly, it is a truly inter-disciplinary study, fusing the 
authors' different expertise into a very impressive mélange of historiography, philosophy, and hermeneutics, culminating with their novel reading of Gadamer. In its totality this work's contribution cannot be understated-it is a major and illuminating study.

\section{Ancient texts in a modern context}

Acknowledgement: This essay was written by Veena R. Howard, California State University, Fresno.

In The Nay Science (Adluri and Bagchee 2014), Vishwa Adluri and Joydeep Bagchee critique the application of so-called critical and scientific methods to Indian texts like the Bhagavad Gitā. In the third chapter, which is over one-hundred and fifty pages long, the authors provide a systematic and exhaustive history of German scholars' interpretations of the Gitā. Adluri and Bagchee underscore how Indian scholars who analyzed the scripture "from the perspective of their own normative and philosophical concerns... risked being labeled 'fundamentalists' or 'religious zealots' or at the very least 'uncritical"' (295). In other words, the native scholar's interpretation was either dismissed or relegated to a lower status within the field of scholarship.

Scholars may find it surprising that Adluri and Bagchee choose to end their erudite and exhaustive study with Gandhi's Gïtā, which is not considered scholarly. By selecting Gandhi's interpretation of the Gitā as the counterexample to the scientific or critical method, the authors confront the Indologists' biases toward Indian thinkers' hermeneutics. The authors evaluate Gandhi's use of the Gïan by arguing that his "reading of the Bhagavad Gitā can help us understand how it is possible to negotiate the various demands of the text meaningfully...and making it hermeneutically productive for one's present" (435). Such an assessment is not without warrant. As we know, Gandhi never claimed to be a scholar or a philosopher; he was a politician (or a "saint-politician" of a unique sort) who drew on the teaching of the Gitā for self-transformation and to substantiate his methods of nonviolence and Satyagraha. Gandhi was neither a "Sanskrit scholar" nor did he "pretend to be one." Furthermore, he was not concerned with the historicity of the Mahabharata. Instead, he called the Gitā his "spiritual dictionary" and "infallible guide." Some scholars have viewed his rendering of the Gitā critically. Adluri and Bagchee, however, present Gandhi's commentary on the Gitāa as an example of alternative to the historical scientific method.

To fully understand the efficacy of ending with "Gandhi on the Gitā," it is important to comprehend how the authors build their critique of the scientific method, which is outlined in the opening of the conclusion, titled "Gandhi on the Gita.."Adluri and Bagchee argue that the language of myths is laden with meaning that needs to be discovered. They quote George Steiner on the insufficiency of historical-critical method in studying sacred stories and poetry:

.... language contains within itself the boundless potential of rediscovery, or recompositions of reality, of articulate dreams, which are known to us as myths, as poetry, as metaphysical conjecture, and the discourse of law. (Adluri and Bagchee 2014, 433).

Regarding "rediscovery, or re-compositions of reality" in texts and the process of meaning-making, the tools of philology or historicism are deficient. Thus, the authors see Gandhi's commentary on the Gitā as working toward a rediscovery of the Gïtā's 
essence (its epistemological, ontological, and spiritual content). In this vein, Adluri and Bagchee raise broad questions and concerns regarding the "displacement of philosophical concerns from thinking, and belief in the ability of a technical method to produce truth" (433). For the authors and for Steiner, historical and scientific methods are not adequate to comprehend the language of myth and poetry. In Adluri and Bagchee's context, "producing truth" means the philosophical essence of the text or Gandhi's concept of "Truth," not merely the facts of the historicity of the caste system and the ideological conflict between Buddhism and Brahmanism that Indologists sought to explore.

According to the Adluri and Bagchee, "to read a text philologically ultimately means to read it thoughtfully" (435). Reading "thoughtfully" is a central concern of Adluri and Bagchee's project in the writing of this book. A scholar and an interpreter is asked to read the text meaningfully for the "present" context (not as a dead document that has lost its value in the present) and "thoughtfully" to gain nourishment. This recalls the Biblical story in which God tells Ezekiel to "eat this scroll; then go and speak to the people of Israel" (Ezekiel 3:1). It is the eating and digesting of the book that creates meaning, not a mere scholarly analysis of its ingredients, its recipe, and its texture. However, a thoughtful reading is not bereft of a method or critical analysis; rather, in addition to these it cultivates a mindset that allows the text to speak to the reader. The text, the Bhagavad-Gitā, invites the reader to read it for the present, to gain sustenance from it.

Adluri and Bagchee next redefine the methods of communication of meaning between the text and its interpreter and show how Gandhi used the Gitā to augment his personal and political philosophy. They critique deconstructionist views of communication and writing, arguing that "the vital process of communication of meaning between an author and a reader is thus neither as rigid as Derrida claims is the case in orality (which he sees as modeled on the commandment of the father to the son) nor as endless as he claims is the case in writing. It is rather, a matter of inheritance and enrichment" (437-38). They provide an alternative, that is, an "enrichment" of the meaning of the text. They show how Gandhi enriched his inherited tradition by giving new meanings to yajña and resisting the "technologization and mechanistic domination of the industrial revolution in which India was reduced to mere labor" (438). The authors give examples of how Gandhi's hermeneutical method enriches his inherited tradition and makes various concepts of the Gitā relevant to his political context, including yajña (which he interprets as not merely ritual action but political action). They also respond to those who accuse Gandhi of reading his "own political and religious ideology into the text" (436), arguing that "for Gandhi, reading a text never occurs in a vacuum and is never divorced from politics, and the correctness of reading is possible from the intellectual, existential, and-most important-ethical struggle of the reader" (436). It is Gandhi's existential and ethical struggle that sets his method of thoughtful interpretation apart of from the thinkers trained in the scientific method.

While I agree with their legitimizing Gandhi's use of the Gìtā I am, however, a bit apprehensive about Adluri and Bagchee's use of term "inheritance." I hope they are 
implying that the text is a common property of all humankind (not just Indians), and that they are inviting the reader of The Nay Science to treat it as such. Likewise, their use of "familial hermeneutic" warrants a reminder in the conclusion, as it serves as a cornerstone on which they build the logic of their argument. Do the authors mean by this term Indian hermeneutical traditions? Perhaps it would be more helpful to remind readers about other examples of other interpreters who also use such hermeneutics.

Despite these concerns, Adluri and Bagchee's last chapter proves exceptional in its resituating of the scholarly discourse. In order to validate their position that Gandhi's interpretation is exemplary, they argue, "the author, the text, and the interpreter are linked as wood, fire, and smoke. Thus, the control of the interpretation is not so much domination over the author's lexical and semantic domain, or over the text in its historical primitivity, but a matter of the self-control of the interpreter" (437). This statement challenges the scientific method's presupposition that the interpreter is simply a scientist in the lab who observes the experiment with a detached mindset.

Though intriguing, this point begs the question: what is meant by self-control? Do the authors believe a person with self-control and discipline is qualified to interpret the Gitā? What role does an intellectual understanding have in interpreting such texts? Certainly, Gandhi read the Gìtā as a living document that was concerned neither with the historicity of the Mahābhārata war nor historicity of the incarnation of Lord Kṛ̣na. Instead, he saw the Gìtā itself as a living teacher and interpreted it in a universal diction. He established a personal relationship - a familial bond-with the text when he compared the Gitā to a mother and a wish-fulfilling cow. However, I am left to wonder what Adluri and Bagchee would have to say about the other twentieth-century interpretations of the Gìtā, including those by Bankim Chandra, Vinoba Bhave, and Sri Aurobindo. Furthermore, how would they respond to Tilak's voluminous commentary of the Bhagavad Gìtā, which presented a distinctly different interpretation, especially on the question of nonviolent struggle?

The authors' climactic point about the hermeneutical strategy for understanding the Gìtā comes toward the end of the chapter. They argue:

The task of interpretation, then, is not one of the mere academic cleverness, but the responsibility of a life lived. Only when the text evaluates the interpreter, only when the interpreter risks herself in the interpretation is the interpretation just and complete (Adluri and Bagchee 2014, 440).

Here, Adluri and Bagchee shift the focus from scholars acting as interpreters of the text to examining how the text evaluates and transforms the reader. This reciprocal relationship between the work and the interpreter allows the text to gradually reveal the mysteries hidden in its language, its embedded metaphors.

The authors' conclusion critiquing the "scientific method" reminds me of Gandhi's critique of Western (material) civilization in his manifesto, Hind Swaraj. Adluri and Bagchee state, 
When truth is traded in for mere empirical correspondence, when ideas are traded in for an assemblage of facts, when minimalism is applauded on the face of global problems, when dialogue is suppressed for the sake of monologue of methodological control, the historical method must be critiqued. (Adluri and Bagchee 2014, 445)

Gandhi was a fierce critic of western civilization's ideologies of hegemony, violence, and material indulgence; he envisioned a culture that is committed to the values of equality, nonviolence, dialogue, and self-control. Adluri and Baghchee's book is an effort to reclaim these values in the arena of scholarship.

Throughout their work, Adluri and Baghee's assertion that the relationship between the reader and the text goes beyond the objectivity of the scientific method leads to their central points about the Gītā. The text of the Gìtā is a living document and the interpreter's relationship with the text makes the interpretation meaningful for the present context. Such a hermeneutic is not grounded in history or mechanics, but is dependent on the reader's relationship with the text.

\section{After orientalism: toward a critique of Indologism}

Acknowledgement: This essay was written by Purushottama Bilimoria, Center for Dharma Studies, Graduate Theological Union and Institute of South Asia Studies, UC Berkeley.

In this archival study (Adluri and Bagchee 2014), Indology is characterized as having been constructed out of three basic ingredients: scientific positivism, historicism, and philology.

In the Introduction and Chapter Four, "The Search for Universal Method," I was struck both by the details with which this story is told and how well it overlaps with my own study that I conducted a decade back and published in 2009 as "A Report on Indologism" (Bilimoria 2009). Shortly, I shall draw some contrast and where I think we not so much differ as how further expansion can be attempted of the story of Indology as an ideology; hence "Indologism" on a par with and as an extension of "Orientalism" (which was the title of another paper: "Post-Orientalism: Indology at Cross-roads," delivered at the World Sanskrit Conference in Melbourne 1994). This might embellish and present a more robust account; indeed, the two papers were born out the deep "hermeneutic of suspicion" in regards to the achievements of European Indology.

At the heart of the book is the thesis that whatever else Indology is and whatever storyline the Germans themselves and their own historians such as Ernst Windisch (whose 1920 work my team in Melbourne translated in large part) recounted, Indology reeks of an ill-conceived theology, albeit German academic theology, through and through. It is this thrust that gives it the privileged stake or veneer of having its historical roots in the method of philology. But really both the "objectivity" (that sets aside subjectivity and prejudices of the ages) made possible through the Wissenschaft of science, in a rather crudely positivist-empiricalist-Newtonian form as science was then understood (before the philosophers of science and certain radically-minded scientists closer to the Second World War disrupted the self-confidence and undermined its excessive methodological claims). Philology was touted as the science of language through which texts were to be read in a certain mode, and this paradigm was not to be doubted or even confused with philosophy or old-style biblical criticism. This was a truly rational, enlightened, secular method that had 
gained much ground already in the careful sifting and study of Semitic and JudeoChristian texts. And indeed, the theology hidden beneath the veneer of rationalism was thoroughly Protestant theology with a few exceptions where someone (Jacobi) is a Catholic and another who worked in a Lutheran seminary, or another a missionary (Hauer) who spent four years in India possibly entrenching the colonizing logic rife in those times. As philology gave way to the new science of linguistics in the twentieth century, Indologists took up the new tools of historical linguistics, structural linguistics, semantics, semiotics, etc., without however moving far from the basic intellectual values associated with philology itself. The fact that Sanskrit played its part in the development of linguistics, via the role of comparative Indo-European linguistics, meant that Sanskritists and Indologists would always feel a close kinship with and attachment to linguisticbased methods of research (see Figueira 1994).

I am not unpersuaded, as I have said something similar in respect of the role of religion/ theology in this enterprise (I will cite myself shortly), and indeed by the mid-twentieth century the suspicion of the role of theology in Religionwissenschaft grew so viral that scholars of comparative religion like Eric J. Sharpe and Gerard van der Leeuw argued to extricate all theological undercurrents from religious studies or the study of religions proper, especially in the comparative modality. Only that this probably never came under question in Indology as the theological thrust after a while died away with the supposed secularization and Anglo-Americanization or globalization of Indology. But one cannot say for sure that, for example, Johaness Bronkhorst (mentioned as a modern-day Indologist) or James Fitzgerald or Patrick Olivelle or Greg Bailey, to name just four, continue the theological motivations of eighteenth/nineteenth or early twentieth-century German or American Indologists such as E. W. Hopkins and Dwight Whitney. Nor can one say that their prejudices (as all scholars come with some of this ingredient) are still rooted somewhere else in the Pandora's box: say, for instance, in an excess of non-self-reflexive reliance on philology? Oblivious to the fact that their practice of translation and commentarial annotation is rooted in a historical tradition with assumptions that are difficult to extricate and set aside, reflected in the rather honest confessional statement Olivelle once made in response to my critique of Indologism: "I simply translate; I know there are historical predecessors I am not far from, and there are limitations I am too well-aware of, biases and so forth; maybe in fifty years time scholars will look at my work and think of the same way we today think of eighteenth and nineteenth-century Indologists: we just have to live it and do our job as best as we can; we at least have more resources and self-awareness than those others did." ${ }^{21}$ He says something along these lines in more nuanced way in his Introduction to the translation of the Upani ads at least also, and does, albeit guarded, justice to the issues I had raised.

Coming back to The Nay Science, I am heartened to see a clear and precise definition of philology (Adluri and Bagchee 2014, 11), where the focus is on criticism/critique. But wasn't there more than that: a good dose of linguistics, comparative mythology, etymological and semantic concordance side with a hard-nosed structuralist approach (even before structuralism was founded by social scientists)? In some ways this erstwhile exercise had nothing to do with theology or biblical criticism, but was seen very much to be a linguistic-scientific project (the sort of thing you see younger scholars doing on philosophical texts from Japan and Europe at the Oriental Studies Conference and increasingly also at the World Sanskrit Conference). The authors are right: anyone can do this regardless of any personal connection with 
the texts, the region it has come from, or its connection with the people who might have made the text part of the repertoire of their cultural Lebenswelt. This is the description given for Indology in general, but it is closely related to how philology is performed.

But I want to focus a bit on the Romantic roots of German Indology. This is important as the larger tapestry within which to understand and appraise the kind of Indology practiced by the select few Indologists treated here, especially in their handling of the Mahābhārata and the Bhagavadgitā. That bigger canvas I have called Indologism (as I said I am not sure who first used this neologism, but it is not unconnected with Pollock's use with a rhetorical question mark in "Deep Orientalism?" (Pollock 1993)). In this way, we could open the analyses to many figures beyond the Holtzmanns, Hauer, Humboldt, Windisch, and so forth. Recall that Hegel (1770-1831) wrote a treatise on Humboldt's German translation of the Bhagavadgītā, which he came to know about from Colebrook (see Adluri and Joydeep, p35 and n21). Little wonder that Gayatri Spivak relies almost entirely on Hegel's work on the Gitā in her "Epics and Ethics" project, not because this is representative of Indology but because of the teleological and historicist excesses that Hegel weaves into his account of the Philosophy of History (and the History and the Philosophy of Religion). Hegel locates India and China in the epistemographic diagram he sketches in respect of the progress of Vernunft or Reason stretched out in the hammock of history on which reclines the concealed Geist (for Adluri and Bagchee's critique of Hegel, see Adluri and Bagchee 2014, 157). While it is noted to be there in Baur's conception of intellectual history, the authors have tended to play down the role of teleology (16 and passim) which does not seem to sit well with more of the emphasis on Semler's idea of perfectibility and Baur's historical-critical method (8). Herder is mentioned in the context of translation of the Bhagavadgitā alongside those by Schlegel and Humboldt (31), but he is important in the larger drive towards the historicization of Indic texts and culture.

A word on historicization is apposite at this point, if I may add some of my own observations (from another work-Bilimoria 2015). The genesis of historicism as a grand philosophical trope goes all the way back via Novalis and Herder to the twelfth-century visionary, Joachim of Fiore, who had proposed that history moves through three phases or epochs (not unlike Hindu yugas, only in reverse), namely the Age of the Father (or of Law, identified with the Old Testament), the Age of the Son (or of Grace, exemplified in the New Testament) and the Age of the Spirit (ecclesia Spiritualis), the "Third Age," which would usher in the Age of John, the Evangelist, outstripping the church. There is a higher order of ascendancy as each Age passes into the next, the last of which escorts history into its apotheosis. Joachim's ideas on the inexorable movement of history continued to be influential from the thirteenth to the sixteenth century and even after. Spectacularly, the night before the Holy Roman Empire fell to Napoleon's thumping wellingtons (boots) at Jena in September 1806, Hegel completed his Phenomenology of the Spirit. The massive tome ends, appropriately, with an ontotheological schema reminiscent of Joachim of Fiore's announcement of a New Age of the Spirit to complete the Ages of the Father and the Son. And like Goethe, Hegel concluded that the irreversible event signaled the end of the Middle Ages (see Lichtheim's introduction to The Phenomenology of Mind [Hegel 1967, xx]).

Hegel would take over this idea and present it as the central doctrine of the Incarnation, which portends, in John Burbidge's rewording, "the divine initiative as passing through three stages that reproduce the first, the second, and the third negation. In the first, God limits himself and becomes finite-an individual man specifically located in 
space and time. In the second, this individual dies; his finitude is cancelled. In the third, the negative force of his death is dissolved, and he becomes universally present as the resurrected Christ" (Burbidge 1992, 126). ${ }^{22}$ History has an inner determination that moves it dialectically through certain necessary phases; in history, Hegel discerns a deeper spiritual regularity underlying various national and folk cultures. Hegel turned to provide a detailed account of the location and status of other people and their cultures in his schema of past and future movement of history. Why? Because Hegel was moved by a universal teleology. For this, Hegel owed a debt to Herder. Herder's interest in the learnings of other cultures, especially of the ancients, among whom he valued most the bygone heritage of the Indo-Europeans, implied that temporal cultures are not necessarily marginal to the present; they may even be central to it; it is only that their memory has receded from sight, along possibly with all its artifacts.

The Romantics, and here we speak of Herder in particular, were impressed by the worthy contribution of Indo-European to the whole history of human thought. For Hegel, this demonstrated that the relative stage of development of the Spirit through the machinations of Reason in each culture, as collective of individuals in a given environ, is reflected inexorably in their respective productions, that is, their thinking, literature, religion, magical practices, social institutions, and the maturity or lack thereof of the apparatus enabling self-determination or freedom in political and civil life. Now this is very important for the architectonic movement, as Hegel effected most if not all of the key changes in European thinking from the 1790s to the 1820s, including in the philosophy of religion. His most sustained engagement in this area appeared in his posthumously published Lectures on the Philosophy of Religion, wherein he provides an ontotheological schema that overrides the stereotypical versions of religions emerging in the science of religions or Religionswissenschaft.

From the late seventeenth century onwards, philologists and linguists had begun to discover the Indo-European family of languages, which rivaled the Semitic lingua in its dating or antiquity, inclusiveness, range of dialects, literary output, and affinities with European speech. Sanskrit drew the greatest attention, in view of its historical links with Ancient Greek, Latin, Old German, Old Lithuanian, and even English.

Extensive study of Hegel and also of Schopenhauer's transcreations of Asian cultures in this context has pointed to the extent to which key European scholars in the nineteenth century had been deeply influenced by this abstract historicist project. But, unlike Joachim of Fiore, they looked for the roots and promises in the Aryanization of history itself, right across the board as it were. Such was the impact of "German romanticism-Wissenschaft" (Pollock 1993, 80) ${ }^{23}$ through their forays into Sanskrit learning and philological discoveries, and impacted in the Schlegels, Franz Bopp, et al., all of whom have been discussed in the context of their work on the Mahābhärata or the Bhagavadgītā. Nietzsche, no insignificant philologist himself, who seemed unaware of the hullabaloo around the Mahābhārata and the Bhagavadgītā, dealt a severe blow to this Romantic tendency, and especially targeted Schopenhauer, remaining skeptical about the possibilities further East, and denigrating the historical Buddha or for that matter Kṛṣna [of the Bhagavadgîtā] for their enervating excesses. Although this did not stop the last metaphysician from transcreating his own version of the Buddha: instead, declaring himself "Europe's Buddha" (see Bilimoria 2008). Nevertheless, it is all grist to the "comparative science of religion/comparative theology" misty mill. 
Such platitudes reinforced the Indian attraction to the idealism of neo-Hegelians like T. H. Green and of F. H. Bradley in due course. Of course, I was heartened to hear that The Nay Science's "direct inspiration [was] ultimately the radical philology of Nietzsche (articulated, among other works, in his The Birth of Tragedy out of the Spirit of Music)" (Adluri and Bagchee 2014, 5, n. 16). I would have liked hear more about this Nietzschean connection.

Voltaire is also interesting in this context. Figueira in her studies examines the work of Voltaire and his quest for an Aryan Ur-text in the Ezour Vedam (Figueira 2002; 2015). Voltaire sought in India a sophisticated culture as far removed as possible from that of the ancient Hebrews. In this respect, ancient India provided him with an alibi in the true sense of the term, an elsewhere upon which he could superimpose his critique of the Judeo-Christian tradition.

Quickly and finally, I wish to move on to a couple of other comments. Other times, some of the Indologists moved around in India; among them mentioned are: Hoernle, Growse, Roer, Brothers Schelling, Grimm, Schrader, Woolner, the French Dupperron whose translation of the Upanișads Hegel read, side by side with Paul Deussen's translation. In response to the intriguing disclaimer, the focus of the present book under review is on two relatively minor German Orientalists: Adolf Holtzmann Sr. and Adolf Holtzmann $\mathrm{Jr}$, with this added rider: "And yet, it is our claim that it is precisely in the work of these and other writers, neglected as marginal and at odds with the image of itself German Indology sought to project (enlightened, rational, posttheological, and postconfessional), that we find the greatest clues to Indology's textual project" (Adluri and Bagchee 2014, 5). It might work for the Mahābhārata in Germany or the German reception of the Mahābhārata.

In terms of the questions "how did they [the German Indologists] view their discipline? In what way did they see themselves as contributing to the task of translating or clarifying Indian literature to European audiences? What were the means, the arguments, or the strategies used to justify their role as official purveyors of Indian culture to these audiences" (3), and so on, I found the studies of latter-day (i.e., twentieth-century) Indologists quite helpful-both for what they say and what they do not say.

\section{Endnotes}

${ }^{1}$ I have discussed the significance of relation to the Gods in the Phaedrus in Plato's Gods and the Way of Ideas (Butler 2011).

${ }^{2}$ See my discussion of this passage in Butler 2013, 217-21.

${ }^{3}$ In Phaedrus 236e the book (Adluri and Bagchee 2014, xiv) gives a better definition of philologos than the standard definition, "fond of speaking," found in Greek lexica (LSJ and the new Brill Dictionary). The discussion between Socrates and Phaedrus gains significance by taking place under a plane-tree (platanos), a pun on the name Platon. With respect to technical philology, it is important to note that the authors do not attack textual groundwork itself, although this is hard to find: Adluri and Bagchee 2014, 19 with n. 82 on "lower criticism"; 399 n. 151, 415 n. 193, 428.

${ }^{4}$ Statements about plurality in The Nay Science include ones at: 399-400, $416 \mathrm{n}$. 197, 424, 445 (dialogue).

${ }^{5}$ These notes date from the first half of 1875. I cite them according to Arrowsmith's translation (Arrowsmith 1973/74). Arrowsmith groups the notes into eight groups, 
corresponding to the numbering of Nietzsche's notebooks in the Goethe- und SchillerArchiv (Arrowsmith uses the older signatures established by Hans Joachim Mette rather than the newer GSA signatures). Within the groups, the notes are serially numbered (the second number inserted in square brackets).

${ }^{6}$ There is also an excellent English edition of this work by M. W. Grenke (Grenke 2004).

${ }^{7}$ See also 5[19] on proper critical method, with The Nay Science (Adluri and Bagchee 2014, 428, first line).

${ }^{8}$ Vishwa Adluri, in conversation.

${ }^{9}$ Written against David Strauss' historical approach to Jesus, this striking dictum also applies to Wagner. Cp. Adluri and Bagchee 2014, chapter 5, for their praise of moves by Gadamer and others from historicism to myth, narrative, and theology.

${ }^{10}$ Vishwa Adluri, in conversation. Consider the important programmatic statement that Indian philosophy and religion are rational, not mystical (Adluri and Bagchee 2014, 432 n. 252). The book promotes "rational soteriology" (421). Cp. Socrates' words concluding Plato's Republic, about the life-and-death story called the myth of Er: "so the muthos was preserved ... and it would save us too" (Rep. 621c).

${ }^{11}$ On the remoteness of Homer's texts not threatening modernity, see Grafton et al. in Wolf 1985, 10-12 and 33. What I call "technical" versus "humanistic" these editors call "historicist" versus "classicist" (Grafton et al., ibid., 11 n. 19, 250). For the "present past" (corresponding to the latter term in the previous two dichotomies), The Nay Science evokes Gadamer (415, 426) and Gandhi (435-38). On Neuhumanismus, see Diehl 1978.

${ }^{12}$ Nietzsche admires Wolf for reforming the gymnasium not as a place "for cultivating academic research but as first and foremost a genuinely holy place consecrated to a higher and nobler education" (Nietzsche 2016 [1872], 33).

${ }^{13}$ The writer Seneca would be appalled at the restrictive proscriptions placed on the reading of him today: "[p]assing in silence over much of what a student of philosophy would look for" (Romm 2014, xv); reducing Seneca's career of thought to his being "a politician in philosophy" (216); the author's proud defense of his own all-out positivism (214). See Seneca, Moral Letter 108, cited above, for his youthful passion for education in philosophy.

${ }^{14}$ See Allan Nadler's review of this book (Nadler 2013).

${ }^{15}$ Simon Price's outstanding article about Delphi (Price 1985) supports The Nay Science. He showed that a false misunderstanding of the oracle, namely the idea that priests corrupted it, arose from Enlightenment anti-clericalism (141-43). His words apply to recently popular geological explanations as well: "We might think it essential to locate an explanation at that level, but this is only because we do not accept the power of Apollo." On the other hand, standard studies of Greek religion, even the great Walter Burkert's, deserve more critical analysis. He seems perplexed: "However difficult it may be for mythological and for conceptual reflection to understand how such a sacrifice affects the god, what it means for men is always quite clear: community, koinonia." "Men" here are modern social scientists; what does this religion understand about gods?! And: "speaking about gods is a matter for poets-a highly unusual manner of speaking...." (Burkert 1985, 58 and 125). In fact, what The Nay Science says about myth, and I have tried to bring out above, forces us to re-evaluate the myth-ritual school of explaining ancient religion in which myths function as justifying charters for acts whose meaning was lost to the participants. That implies that myth too has lost meaning. For Tylor and Frazer, the theory described a stage of development of human thought in 
which people attempt to control nature. For Burkert, the acts forge society. The existential import of myth is ignored, surely in part because to implicate myth in religion strikes too close to home for religions founded on the Bible. About Socrates, The Nay Science suggests one way to study the history of scholars' tending to make Socrates in their own images and often missing what matters (a political or philosophical criminal? all-questioning or knowing? how religious? etc.). Here is one minor but telling current example. A popular textbook of Ancient Greek, created at a Lutheran college to teach both Classical and New Testament Greek, includes the made-up practice sentence: "[They asked Socrates,] What is your opinion about the fate of the body?" This is nonsensical. The fate of the body afer death is obvious and of no interest except in the context of the Christian (and other, but definitely non-Classical) belief in a bodily afterlife. Socrates cared about the soul (says Plato), and the idea of the immortality of the soul is more spiritual than the belief in bodily resurrection.

${ }^{16}$ This is not a mere matter of speculation. The structuralist history of philosophy in Brazil inherited from France had precisely this effect in stifling the developing philosophical tradition there, rejecting it all as the work of "amateurs" (see Cabrera 2013). As in the case of German Indology, there was here a claim to unique methodological access, an ideal of "rigor" that parallels the role of "Wissenschaftlichkeit" detailed by Adluri and Bagchee.

${ }^{17}$ And it is doing this in a number of ways: by including the early Christian fathers within the scope of ancient philosophy as in Karamanolis (2013); by investigating the role of the gods in Plato and Aristotle as in Bodeus (1992) and in Schefer (1996); by seeing how theurgy is integrated into the philosophy of late Platonists as in Addey (2014) and in Shaw (1995); by investigating Plotinus's dialogue with the gnostics as in Mazur $(2003,2004)$ to name a few examples.

${ }^{18}$ Some of this has been done by Tigerstedt, for instance, who has shown the role of Protestant and Catholic polemics in bringing down the Neoplatonic interpretation of Plato (see Tigerstedt 1974).

${ }^{19}$ See Hankey (2013) on the development of the autonomy of philosophy following upon Thomas's distinction between the light of reason and the light of faith, partly in order to justify a potestas indirecta of the Church in secular matters.

${ }^{20}$ Thank you to the students in the graduate readings seminar "Germany and the World" in Spring 2015, who read The Nay Science and provided valuable feedback: Robert Feeney, Gino Galli, Natasja Graske, Michael Habib, Daniel Halverson, and Sean Mallen.

${ }^{21}$ Remarks at the inaugural meeting of the Hinduism Group at the American Academy of Religions in 1998 (my paraphrase).

${ }^{22}$ See also Tillich 1959; Edward Said's Culture and Imperialism (Said 1993) is a more helpful book in this context than his Orientalism (Said 1978).

${ }^{23}$ The hyphenation is Pollock's; see Bilimoria 2009, n. 18. 
Bilimoria, Purushottama. 2015. Philosophical orientalism in comparative philosophy of religion: Hegel to Habermas (\& Zîzêk). Cultual Oriental 2(2): 47-63.

Bodeus, Richard. 1992. Aristote et la Theologie des Vivants Immortelles. Quebec-Paris: Bellarmin-Les Belles Lettres. Burbidge, John W. 1992. Hegel on logic and religion: The reasonableness of Christianity. Albany: State University of New York Press. Burkert, Walter. 1985. Greek religion. Translated by John Raffan. Cambridge: Harvard University Press.

Butler, Edward P. 2011. Plato's Gods and the Way of Ideas. Diotima: Review of Philosophical Research 39: 73-87.

Butler, Edward P. 2013. Opening the Way of Writing: Semiotic Metaphysics in the Book of Thoth. In April D. DeConick, Gregory Shaw, and John D. Turner, eds. Practicing Gnosis: Ritual, Magic, Theurgy and Liturgy in Nag Hammadi, Manichaean and Other Ancient Literature. Essays in Honor of Birger A. Pearson, 215-247. Leiden: Brill.

Cabrera, Julio. 2013. Diário de um Filósofo no Brasil. ljuí: Editora UNIJUI.

Chakrabarty, Dipesh. 2007. Provincializing Europe: Postcolonial thought and historical difference. Princeton: Princeton University Press.

de Certeau, Michel. 1988. The writing of history. Translated by Tom Conly. New York: Columbia University Press.

Deresiewicz, William. 2014. Excellent Sheep: The Miseducation of the American elite and the way to a meaningful life. New York: Free Press.

Desai, Mahadev trans. The Bhagavad Gita according to Gandhi. CA: North Atlantic Books, 2009.

Diehl, C. 1978. Americans and German scholarship, 1770-1870. New Haven: Yale University Press.

Figueira, Dorothy M. 1994. Translating the orient: reception of Sakuntala in Nineteenth-Century Europe. Albany: State University of New York Press.

Figueira, Dorothy M. 2002. Anyans, Jews, Brahmins: Theorizing authority through Myths of identity. Albany: State University of New York Press.

Figueira, Dorothy M. 2015. The Hermeneutics of suspicion cross-cultural encounters with India. London/Sydney: Bloomsbury Publishing.

Germana, Nicholas A. 2009. The Orient of Europe: The Mythical Image of India and Competing Images of German National Identity. Newcastle upon Tyne: Cambridge Scholars.

Grenke, M.W. 2004. On the future of our educational institutions. South Bend: St. Augustine's Press.

Hacker, Paul. 1961. Zur Methode der geschichtlichen Erforschung der anonymen Sanskritliteratur des Hinduismus. Vortrag gehalten auf dem XV. Deutschen Orientalistentag Göttingen 1961. Zeitschrift der Deutschen Morgenländischen Gesellschaft 111 (no. 2): 483-92.

Hegel, G. W. F. 1967. Phenomenology of Mind. Introduction by George Lichtheim. Translated by J.B. Baillie. New York: Harper Torchbooks.

Jasnow, Richard, Karl-Th. Zauzich. 2005. The Ancient Egyptian Book of Thoth: A Demotic Discourse on Knowledge and Pendant to the Classical Hermetica. Wiesbaden: Harrassowitz.

Jasnow, Richard, Karl-Th. Zauzich. 2014. Conversations in the House of Life: A New Translation of the Ancient Egyptian Book of Thoth. Wiesbaden: Harrassowitz.

Karamanolis, George. 2013. The philosophy of early Christianity. Durham: Acumen.

Lenz, John R. 2011. How Epicurean science saves humanity in Lucretius. In Lucretius: his continuing influence and contemporary relevance, ed. Timothy J. Madigan and David B. Suits, 89-106. Rochester: RIT Press.

Mazur, Zeke. 2003. Unio Magica, Part 1: on the magical origins of plotinus' Mysticism. Dionysius 21: 23-52.

Mazur, Zeke. 2004. Unio Magica, Part 2: Plotinus, theurgy, and the question of ritual. Dionysius 22: 29-56.

McGrath, S.J. 2008. Heidegger: a very critical introduction. Grand Rapids: Wm. B. Eerdmans Publishing Co.

Melville, Herman. 1851. Moby-Dick. Norton Critical Editions, edited by H. Parker and H. Hayford. New York: W.W. Norton, 2001.

Nadler, Allan. What Jesus Wasn't: Zealot. Review of Zealot: The Life and Times of Jesus of Nazareth, by Reza Aslan. Jewish Review of Books, August 11, 2013.

Nietzsche, Friedrich. 1909 [1869]. Homer and Classical Philology. Translated by J. M. Kennedy. In The Complete Works of Friedrich Nietzsche, 145-70. Edinburgh and London: T. N. Foulis

Nietzsche, Friedrich. 1995. Unpublished writings from the period of unfashionable observations. Translated by Richard T. Gray. Stanford: Stanford University Press.

Nietzsche, Friedrich. 2001 [1887]. The gay science: with a prelude in German rhymes and an appendix of songs. Translated by J. Nauckhoff and Adrian Del Caro. Cambridge: Cambridge University Press

Nietzsche, Friedrich. 2016 [1872]. Anti-Education: On the Future of Our Educational Institutions. Translated by Damion Searls, edited by Paul Reitter and Chad Wellmon. New York: New York Review of Books

Pollock, Sheldon. 1993. Deep orientalism? Notes on Sanskrit and power beyond the Raj. In Orientalism and the postcolonial predicament: perspectives on South Asia, ed. Peter van der Veer and Carol A. Breckenridge, 76-133. Philadelphia: University of Pennsylvania Press.

Pollock, Sheldon. 2009. Future philology? the fate of a soft science in a hard world. Critical Inquiry 35: 931-61.

Price, Simon. 1985. Delphi and Divination. In Greek religion and society, ed. P.E. Easterling and J.V. Muir, 28-54. Cambridge: Cambridge University Press.

Reitter, Paul and Chad Wellmon. Introduction in Nietzsche 2016 [1872].

Romm, James. 2014. Dying every day: Seneca at the Court of Nero. New York: Random House.

Said, Edward. 1978. Orientalism. New York: Pantheon.

Said, Edward. 1993. Culture and imperialism. New York: Knopf.

Schefer, Christina. 1996. Platon und Apollon: vom Logos zurück zum Mythos. Sankt Augustin: Academia Verlag.

Shaw, Gregory. 1995. Theurgy and the soul: the Neoplatonism of lamblichus. University Park: Pennslvania State University Press.

Sherma, Rita D. 2011. Introduction: a Hermeneutics of subjectivity. In Woman and Goddess in Hinduism: Reinterpretations and Re-envisionings, ed. Tracy Pintchman and Rita D. Sherma, 1-16. New York: Palgrave Macmillan.

Smith, Jonathan Z. 2010. Tillich['s] Remains.... Journal of the American Academy of Religions 78(4): 1139-170.

Stache-Rosen, Valentina. 1990. German Indologists: biographies of scholars in Indian studies writing in German. Delhi: Max Müller Bhavan. 
Sullivan, Bruce M. 1990. Kṛșna Dvaipāyana Vyāsa and the Mahābhārata: A New Interpretation. Leiden: Brill. 2nd edition: Seer of the Fifth Veda. Delhi: Motilal Banarsidass, 1999.

Sullivan, Bruce M. 2001. "The Whale Avatar of the Hindoos in Melville's Moby Dick." Literature \& Theology 15, no. 4 (December): 358-72; with contribution by P. W. Hall.

Tigerstedt, Eugène. 1974. The decline and fall of the Neoplatonic interpretation of Plato: an outline and some observations. Societas Scientarum Fennica: Helsinki.

Tillich, Paul. 1959. Theology of culture. Oxford: Oxford University Press.

Tillich, Paul. 2001 [1957]. Dynamics of Faith. New York: HarperCollins

Wayne, Hankey. 2013. All given and all received. http://www.dal.ca/content/dam/dalhousie/pdf/fass/Classics/Hankey/73. \%20All\%20Given\%20and\%20All\%20Received.pdf.

Wezler, Albrecht. 1993. Towards a reconstruction of Indian cultural history: observations and reflections on 18th and 19th century Indology. Studien zur Indologie und Iranistik 18: 305-29.

Windisch, Ernst. 1917-20. Geschichte der Sanskrit Philologie und indischen Altertumskunde, 2 vols. Berlin: de Gruyter

Wolf, F.A. 1985. Prolegomena to Homer 1795. Translated by A. Grafton, G.W. Most, and J. E. G. Zetzel. Princeton: Princeton University Press

Young, Julian. 2010. Friedrich Nietzsche: a philosophical biography. Cambridge: Cambridge University Press.

Submit your manuscript to a SpringerOpen ${ }^{\odot}$ journal and benefit from:

- Convenient online submission

- Rigorous peer review

- Immediate publication on acceptance

- Open access: articles freely available online

- High visibility within the field

- Retaining the copyright to your article

Submit your next manuscript at $>$ springeropen.com 